\author{
Case Study \\ www.ijrap.net (ISSN:2229-3566)
}

\title{
AYURVEDIC MANAGEMENT OF MUSCLE CONTUSION WITH RESULTANT HAEMATOMA: A CASE STUDY
}

\author{
Tinkle Rani ${ }^{* 1}$, Vishal Aggarwal ${ }^{1}$, Arun Gupta ${ }^{2}$
}

${ }^{1}$ PG Scholar, Panchakarma Department, Chaudhary Brahm Prakash Ayurved Charak Sansthan, New Delhi, India

${ }^{2}$ Professor, HOD, Panchakarma Department, Chaudhary Brahm Prakash Ayurved Charak Sansthan, New Delhi, India

Received on: 12/07/20 Accepted on: 25/08/20

\author{
*Corresponding author \\ E-mail: tinklekhowal.tk@gmail.com
}

DOI: 10.7897/2277-4343.1105173

\begin{abstract}
A Muscle Contusion is a deep bruise due to traumatic blow to the soft structures such as muscle fibres, connective tissues and or blood vessels. In sports activity, Quadriceps Muscle Contusion is a very common complaint. It is a type of closed wound in which there is crushing of the muscle fibres which only allows bleeding beneath the skin. Symptoms include discolouration, swelling, pain and limitation of motion. As per Ayurvedic perspective, Quadriceps Muscle Contusion should be considered as Abhighata Janit Shoth. The present case study aims to investigate whether Ayurvedic intervention can be used as a treatment modality for acute sports injuries such as Quadriceps Muscle Contusion. A 19 years old girl came to the OPD of CBPACS with clinical features indicative of Quadriceps Muscle Contusion with resultant Hematoma. This case of was managed by Ayurvedic intervention of Kaishor Guggulu, Brihat Manjishthadi Kwath and Dashanga Lepa local application at OPD level for 14 days. The treatment gave very promising results with an overall improvement of about $76.66 \%$ in the subjective parameter used i.e. Oswestry's disability index from 30 to 07 , VAS improved from $8 / 10$ to $2 / 10$, at the end of 14 days of treatment.
\end{abstract}

Keywords: Quadriceps Muscle Contusion, Abhighata Janit Shoth, Kaishor Guggulu, Dashanga Lepa, Brihat Manjishthadi Kwath.

\section{INTRODUCTION}

In the present era, everyone is aware of the benefits of getting exercise or involving in some kind of sports activity. But at the same time improper sports practice may also be one of the way of putting your body at risk. Sports injuries side lines thousands of people each year, thus makes even stronger necessity for the early treatment of the same. A quadriceps contusion is a traumatic blow, a deep bruise to the anterior lateral or medial aspect of the thigh $^{1}$. If examination confirms an area of swelling and tenderness with (terrible) pain on passive stretch and active contraction, the diagnosis is Quadriceps contusion with resultant hematoma ${ }^{2}$. A systematic review resulted in a frequency from $10 \%$ to $40 \%$ of all football injuries were categorized as contusion, strains or sprains ${ }^{3}$. A direct blow to the quadriceps causing significant muscle damage is the usual mechanism of this injury. In comparison to strains, contusions will cause rupture to the muscle fibres at or directly adjacent to the area of impact which may often lead to hematoma formation within the muscle causing pain and loss of motion. A massive blunt force mostly to the anterior or lateral thigh cause rupture to the muscle fibres. In the beginning there will be negligible symptoms, but after 24 hours this will lead to hematoma formation within the muscle causing pain, swelling, stiffness and impairment of range of motion of the affected limb.

In Ayurveda its features resembles with Agantukshoth (Exogenous Oedema) which has been elaborately mentioned by Acharya Charaka in Chikitsa Sthana. In that section they explained about its Nidana, Poorvaroopa, Roopa and Chikitsa in depth. Likewise Acharya Sushruta also in Chikitsa Sthana told about the injuries occurs due to external trauma and called it as abhighata or external trauma. Its causes as given in text are some external trauma like by wood, stones, weapons or any blunt metallic structures ${ }^{4}$. As per the text, in Abhighataj Shotha initially there will be vitiation of Vata and Rakta dosha which manifests its symptoms in Bahya tvak that is superficial skin. Further it will cause aggravation of Kapha, Rakta and Pitta. Which results into Marga avrodha means cause obstruction in the passage. Now this vitiated Vata Dosha, goes into the superficial skin layers shows its signs and symptoms as swelling, Gaurava (heaviness), Utsedha (swelling) and Sira Tanutwa (Vasodilatation) of the affected area ${ }^{5}$. As per Acharya Charaka its treatment modalities are same as for Visarpa Chikitsa and Vatarakta Chikitsa ${ }^{6}$. For Bahi Parimarjana chikitsa treatment for Vatarakta is application of Alepa, Abhyanga, Parisheka and Upanaha, while in Visarpa, Pradeha (for Prasadana) should be used. In this present case study keeping all these points in view it was clear that there was main dushti of Kapha, Rakta and Vata and the drugs used should be Vata-Kapha shamaka and Rakta Prasadaka. So, we selected Brihat Manjisthadi Kwath, Kaishor Guggulu for oral and Dashanga Lepa for external application and studied there effect.

\section{MATERIALS AND METHODS}

\section{Patient Information}

A 19 year old female patient, visited in OPD of Chaudhary Brahm Prakash Ayurved Charaka Sansthan, Khera Dabar, New Delhi, with the following details:

\section{Chief complaints}

- Pain, swelling and discoloration of left thigh at the anterior region since two days.

- Difficulty in walking without support since two days.

- Difficulty in performing day to day even simpler activities like getting up from a chair since two days. 


\section{H/O present illness}

According to the patient she was asymptomatic 2 days back and was playing a football match in which she suddenly got a direct blow on her left thigh at the anterior region from one of the opponent player's knee, which resulted her side line from the ongoing match with the development of mild pain for that time being at the same region, with following pain features

- Site - left knee, Anterior view, just above the knee

- Onset-Gradual

- Character - Ache, Stabbing, tearing pain in nature

- Radiation - Non-radiating

- Associations - associated with swelling, tenderness and mild bruising of the same site

- Aggravations - on movement, getting up from sitting posture

- Time course - continuous pattern (present at night also)

- Exacerbating/relieving factors - rest and elevation of the same limb

\section{RESULT AND DISCUSSION}

- Severity - VAS acc. to the patient $8 / 10$

She herself took pain killers which gave symptomatic temporary relief, but reappeared after a couple of hours.

\section{1) Panchakarma treatment}

Upanaha with Dashanga Churna local application in sufficient quantity over the affected site, twice a day with lukewarm Sesame oil for 14 days

\section{2) Palliative (shaman) treatment}

1. Kaishor Guggulu -2 tab (500 mg) twice a day with lukewarm water for 14 days

2. Brihat Manjishthadi Kwath $-50 \mathrm{ml}$ twice a day for 14 days

The study was carried out as per International conference of Harmonization-Good Clinical Practices Guidelines (ICH-GCP).

Table 1: Clinical Examination (before and after intervention)

\begin{tabular}{|c|c|c|}
\hline & Before Treatment & After Treatment \\
\hline Gait & Antalgic with short steps & Normal \\
\hline Inspection & $\begin{array}{c}\text { Visible swelling of the left anterior thigh with bluish discoloration (without any } \\
\text { bleeder points), She was supported by two of her friends while walking and getting up } \\
\text { from the chair. }\end{array}$ & $\begin{array}{c}\text { No visible swelling present, } \\
\text { patient can now walk } \\
\text { without any support. }\end{array}$ \\
\hline Palpation & $\begin{array}{c}\text { Warmth present at the affected site. Tenderness (grade } 2 \text { - tender with winces) of the } \\
\text { affected site present. Palpation was done to localize the pain and exact site of muscle } \\
\text { damage and also to determine if there is any associated injury present or not, but there } \\
\text { was no such findings present. }\end{array}$ & $\begin{array}{c}\text { Minimal tenderness present, } \\
\text { that too on deep palpation. }\end{array}$ \\
\hline $\begin{array}{c}\text { Measurement of } \\
\text { knee flexion }\end{array}$ & $45^{0}-90^{0}$ passive flexion, limited range of motion & $\begin{array}{c}\text { Full range of motion, both } \\
\text { active and passive. }\end{array}$ \\
\hline
\end{tabular}

Table 2: Assessment criteria: By Oswestry Disability Index

\begin{tabular}{|c|c|c|}
\hline S. No. & Questionnaire & Score \\
\hline \multicolumn{3}{|c|}{ Section - I: Pain Intensity } \\
\hline 1. & I have no pain at the moment & 0 \\
\hline 2. & The pain is very mild at the moment & 1 \\
\hline 3. & The pain is moderate at the moment & 2 \\
\hline 4. & The pain is fairly severe at the moment & 3 \\
\hline 5. & The pain is severe at the moment & 4 \\
\hline 6. & The pain is worst imaginable at the moment & 5 \\
\hline \multicolumn{3}{|c|}{ Section - II: Personal Care } \\
\hline 1. & I can look after myself normally without causing extra pain & 0 \\
\hline 2. & Ican look after myself normally but cause extra pain & 1 \\
\hline 3. & It is painful to look after myself and I am slow and careful & 2 \\
\hline 4. & I need some help but manage most of my personal care & 3 \\
\hline 5. & I need help every day in most aspects of self-care & 4 \\
\hline 6. & I do not get dressed, I wash with difficulty and stay in bed & 5 \\
\hline \multicolumn{3}{|c|}{ Section-III Lifting } \\
\hline 1. & I can lift heavy weighs without extra pain & 0 \\
\hline 2. & I can lift heavy weighs but it gives extra pain & 1 \\
\hline 3. & $\begin{array}{l}\text { Pain prevents me from lifting heavy objects but I can } \\
\text { manage if they are conveniently placed e.g. on a table }\end{array}$ & 2 \\
\hline 4. & $\begin{array}{c}\text { Pain prevents me from lifting heavy weights, but I can manage light } \\
\text { to medium weights if they are conveniently positioned }\end{array}$ & 3 \\
\hline 5. & I can lift very light weights & 4 \\
\hline 6. & I cannot lift or carry anything at all & 5 \\
\hline \multicolumn{3}{|c|}{ Section -IV Walking } \\
\hline 1. & Pain does not prevent me walking any distance & 0 \\
\hline 2. & Pain prevents me from walking more than 1 mile $(1.6 \mathrm{~km})$ & 1 \\
\hline 3. & Pain prevents me from walking more than $1 / 2$ mile & 2 \\
\hline 4. & Pain prevents me from walking more than $1 / 4$ mile & 3 \\
\hline 5. & I can only walk using a stick or crutches & 4 \\
\hline 6. & I am in bed most of time & 5 \\
\hline
\end{tabular}


Tinkle Rani et al / Int. J. Res. Ayurveda Pharm. 11 (5), 2020

\begin{tabular}{|c|c|c|}
\hline \multicolumn{3}{|c|}{ Section-V Sitting } \\
\hline 1. & I can sit in any chair as long as I like & 0 \\
\hline 2. & I can only sit in my favourite chair as long as I like & 1 \\
\hline 3. & Pain prevents me sitting more than one hour & 2 \\
\hline 4. & Pain prevents me from sitting more than 30 minutes & 3 \\
\hline 5. & Pain prevents me from sitting more than 10 minutes & 4 \\
\hline 6. & Pain prevents me from sitting at all & 5 \\
\hline \multicolumn{3}{|c|}{ Section VI Standing } \\
\hline 1. & I can stand as long as I want without extra pain & 0 \\
\hline 2. & I can stand as long as I want but it gives me extra pain & 1 \\
\hline 3. & Pain prevents me from standing for more than 1 hour & 2 \\
\hline 4. & Pain prevents me from standing for more than $30 \mathrm{~min}$. & 3 \\
\hline 5. & Pain prevents me from standing for more than $10 \mathrm{~min}$ & 4 \\
\hline 6. & Pain prevents me from standing at all & 5 \\
\hline \multicolumn{3}{|c|}{ Section -VII Sleeping } \\
\hline 1. & My sleep never disturbed by pain & 0 \\
\hline 2. & My sleep occasionally disturbed by pain & 1 \\
\hline 3. & Because of pain my sleep is less than 6 hours & 2 \\
\hline 4. & Because of pain my sleep is less than 4hours & 3 \\
\hline 5. & Because of pain my sleep is less than 2 hours & 4 \\
\hline 6. & Pain prevents me sleeping at all & 5 \\
\hline \multicolumn{3}{|c|}{$\begin{array}{l}\text { Section VIII Sex Life (if applicable) } \\
\end{array}$} \\
\hline 1. & My sex life is normal and causes no extra pain & 0 \\
\hline 2. & My sex life is normal but cause some extra pain & 1 \\
\hline 3. & My sex life is nearly normal but is very painful & 2 \\
\hline 4. & My sex life is severely restricted by pain & 3 \\
\hline 5. & My sex life is nearly absent because of pain & 4 \\
\hline 6. & Pain prevents in any sex life at all & 5 \\
\hline \multicolumn{3}{|c|}{ Section IX Social Life } \\
\hline 1. & My social life is normal and gives me no extra pain & 0 \\
\hline 2. & My social life is normal but increases the degree of pain & 1 \\
\hline 3. & $\begin{array}{l}\text { Pain has no significant effect on my social life apart from } \\
\text { limiting my more energetic interests e.g. Sports }\end{array}$ & 2 \\
\hline 4. & $\begin{array}{l}\text { Pain has restricted my social life and I do not go out as } \\
\text { often }\end{array}$ & 3 \\
\hline 5. & Pain has restricted my social life to my home & 4 \\
\hline 6. & I have no social life because of pain & 5 \\
\hline \multicolumn{3}{|c|}{ Section X Travelling } \\
\hline 1. & I can travel without pain & 0 \\
\hline 2. & I can travel anywhere but it gives me extra pain & 1 \\
\hline 3. & Pain is bad but I manage journeys over two hours & 2 \\
\hline 4. & Pain restricts me to journeys of less than one hour & 3 \\
\hline 5. & Pain restricts me to short journeys of under $30 \mathrm{~min}$. & 4 \\
\hline 6. & $\begin{array}{l}\text { Pain prevents me from travelling except to receive } \\
\text { treatment }\end{array}$ & 5 \\
\hline
\end{tabular}

Table 3: Total Score of Oswestry Disability Index (Before and After Treatment)

\begin{tabular}{|c|c|c|c|c|}
\hline S. No. & Sign and Symptoms & $\begin{array}{c}\text { Score } \\
\text { Before Tt. }\end{array}$ & $\begin{array}{c}\text { Score } \\
\text { After Tt. }\end{array}$ & Result in\% \\
\hline 1 & Pain intensity & 4 & 1 & $75 \%$ \\
\hline 2 & Personal care & 3 & 0 & $100 \%$ \\
\hline 3 & Lifting & 3 & 1 & $67 \%$ \\
\hline 4 & Walking & 4 & 1 & $75 \%$ \\
\hline 5 & Sitting & 3 & 0 & $100 \%$ \\
\hline 6 & Standing & 4 & 1 & $75 \%$ \\
\hline 7 & Sleeping & 2 & 0 & $100 \%$ \\
\hline 8 & Sex life & $\mathrm{N} \backslash \mathrm{A}$ & $\mathrm{N} \backslash \mathrm{A}$ & $\mathrm{N} \backslash \mathrm{A}$ \\
\hline 9 & Social life & 3 & 2 & $33 \%$ \\
\hline 10 & Travelling & 4 & 1 & $75 \%$ \\
\hline \multicolumn{2}{|c|}{ Total } & 30 & 7 & $76.66 \%$ \\
\hline
\end{tabular}

N/A- not applicable 


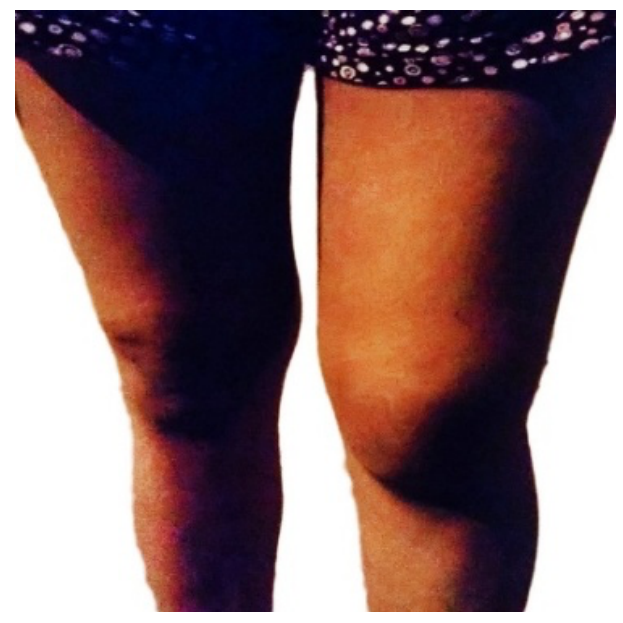

Figure 1: Before Treatment

As per the modern medicament, treatment objectives for Muscle Contusion include relief in pain and improvement of range of motion in an attempt to improve the performance and an early return to sport. For which PRICE (protection, rest, ice, compression and elevation) protocol is usually recommended shortly after the injury to protect the injured part from further damage. The other treatment options include use of NSAIDS and physiotherapy.

In the current case, Swelling and tenderness with terrible pain at the anterior thigh post trauma confirms the diagnosis of Quadriceps Muscle Contusion with resultant Hematoma. As previously explained, Vata, Pitta and Kapha Shamaka, Rakta Prasadaka and Shoth Nashaka Chikitsa is being considered, hence the prescription letter for the current case contains Dashanga lepa Upanaha, Kaishor Guggulu and Brihat Manjishthadi Kwath for 14 days.

Dashanga lepa Upanaha was selected for external application over the affected area as it is described as Shophaghna (antiinflammatory), Kushthaghna (for treating skin disorder), Visarpa Nashaka and Jwarahara (anti-pyretic) remedy. Since Dashanga lepa contains most drugs with Kashaya and Tikta Rasa, hence reducing oedema probably due to Dhatu Shoshaka effects of the same rasas. Dashanga lepa reduces all cardinal features of inflammation as Pain (Dolour), Oedema (Tumour), Erythema (Rubor) and Temperature (Calor) ${ }^{8}$.

Kaishor Guggulu is anti-allergic, anti-bacterial and blood purifying in nature ${ }^{9}$. It is known to have analgesic and antiinflammatory activity also. It can be used to support healthy joints (in Gout), muscles (in Fibromyalgia), in back pain and connective tissue disorders (like sports injuries) ${ }^{10}$.

Brihat Manjishthadi Kwath was chosen, since it contains maximum drugs with Tikta rasa abundance, which makes it suitable for Kapha-pittaghna action. Thus, by the virtue of the above properties it acts on diseases like Kushtha, Jwara and Vatarakta which has dominancy of Pitta dosha and Rakta as dushya ${ }^{11}$. Along with this, it also possesses the property of Rakta Prasadana, Vishaghna, Kushthaghna, Kandughna and Daha Prashamana. Thus makes this Kwath useful in pacifying Raktaja disorders, hence proving its necessity to be used in the present case.

It was observed that the patient improved significantly showing an overall improvement of about $76.66 \%$ in the subjective parameter used i.e. Oswestry's disability index from 30 to 07 ,

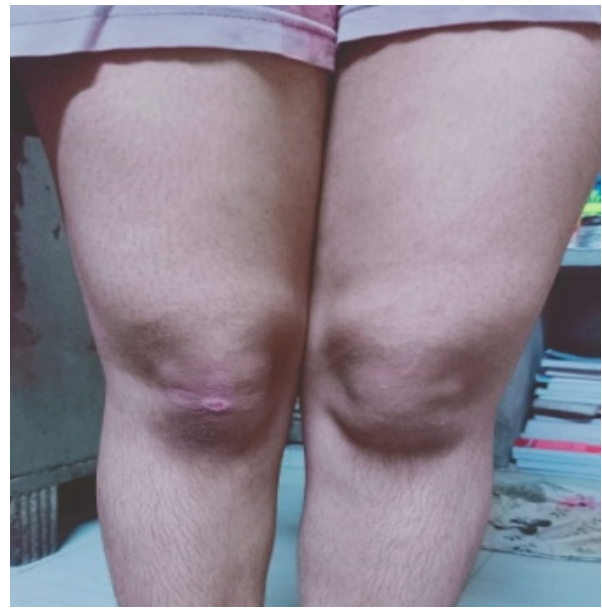

Figure 2: After Treatment

VAS improved from $8 / 10$ to $2 / 10$ and overall, as per the patient it improved to $70 \%$ at the end of 14 days of treatment.

\section{CONCLUSION}

The final take-away message from the above case suggests that Ayurvedic intervention is equally potent in the management of acute sports injuries like Quadriceps Muscle Contusion with resultant Hematoma. Ayurvedic management consisting of Kaishor Guggulu, Brihat Manjishthadi Kwath and Dashanga Lepa was found very effective for the management of Quadriceps Muscle Contusion. The observed benefits may be attributed due to antibacterial and blood-purifying properties of Kaishor Guggulu; Rakta prasadana, Vishaghna (anti-bacterial) and Daha Prashamana property of Brihat Manjishthadi Kwath and antiinflammatory and Visarpa nashaka action of Dashanga Lepa. The findings of this case report suggests that with above Ayurvedic intervention, Quadriceps Muscle Contusion with resultant Hematoma can be managed. Further the findings needs to be confirmed and validated on larger scale to draw final conclusion.

\section{REFERENCES}

1. Kary JM. Diagnosis and management of quadriceps strains and contusions. Current reviews in musculoskeletal medicine 2010 Oct 1; 3(1-4): 26-31.

2. Kary JM. Diagnosis and management of quadriceps strains and contusions. Current reviews in musculoskeletal medicine. 2010 Oct 1; 3 (1-4):26-31.

3. Huntoon EA. Essentials of Physical Medicine and Rehabilitation. In Mayo Clinic Proceedings 2003 Apr 1; 78(4): 291. Elsevier.

4. Shastri K. Shyawthuchikitsa. In: Pandeya, G (ed.) Charaka Samhita. Varanasi, India: Chaukhambha Sanskrit Sansthan; 2012. p. 294.

5. Shastri K. Shyawthuchikitsa. In: Pandeya, G (ed.) Charaka Samhita. Varanasi, India: Chaukhambha Sanskrit Sansthan; 2012. p. 294-295.

6. Shastri K. Shyawthuchikitsa. In: Pandeya, G (ed.) Charaka Samhita. Varanasi, India: Chaukhambha Sanskrit Sansthan; 2012. p. 314.

7. Oswestry Low Back Disability Questionnaire - Rehabilitation [Internet]. [Cited 2020 Jul 09]. Available from: http://www.rehab.msu.edu/_files/_docs/ Oswestry_Low_Back_Disability.p.pdf

8. Ashish S, Gupta S.J. Efficacy of Dashanga Lepa in the Management of Vrana Shopha (Cellulitis): A Preliminary Clinical Study. IJAM 2013; 4(3): 227-236. 
Tinkle Rani et al / Int. J. Res. Ayurveda Pharm. 11 (5), 2020

9. Srikanta Murthy, K.R. Sharangadhara Samhita. (Reprint 2012 edition). Varanasi, India: Chaukhambha Orientalia; 2012.

10. Lather A, Gupta V. An Ayurvedic Polyherbal Formulation Kaishor Guggulu: A Review. IJPBA 2011; 2(1): 497-503.

11. Joshi V. A Literary Scientific Study on Evaluation of Manjishthadi Kwatha. Indian Journal of Ancient Medicine and Yoga 2012; 5(3): 157-168.

\section{Cite this article as:}

Tinkle Rani et al. Ayurvedic management of Muscle contusion with Resultant Haematoma: A Case Study. Int. J. Res. Ayurveda Pharm. 2020;11(5):228-232 http://dx.doi.org/10.7897/2277$\underline{4343.1105173}$

\section{Source of support: Nil, Conflict of interest: None Declared}

Disclaimer: IJRAP is solely owned by Moksha Publishing House - A non-profit publishing house, dedicated to publishing quality research, while every effort has been taken to verify the accuracy of the content published in our Journal. IJRAP cannot accept any responsibility or liability for the site content and articles published. The views expressed in articles by our contributing authors are not necessarily those of IJRAP editor or editorial board members. 